Kóródi Márta

\title{
Az ifjúsági turizmus motivációi francia és angol egyetemisták megkérdezése alapján
}

Márta Kóródi: The Youth Tourism Motivations Based on Interviews French and English Students

\begin{abstract}
The study summarizes the results of two short term research study visits, and the outline of the situation of the Hungarian topic. The results of surveys conducted among students of higher educational institutes of the three cities in the three countries (Bordeaux - France, Durham United Kingdom, Szolnok - Hungary) are presented is comparison with highlighted of similarities and differences. The identified variations of costumer's habits are useful for development of supply.
\end{abstract}

Key words: youth tourism, motivation, travel decision

ÖSSZEFOGLALÓ

Két külföldi kutatói rövid tanulmányút eredményeit foglalja össze a tanulmány a téma magyarországi helyzetképének felvázolásával. A három ország három városának (Bordeaux Franciaország, Durham - Egyesült Királyság, Szolnok - Magyarország) felsőoktatásban tanuló diákjai körében végzett felmérés elemzésének eredményei összehasonlítva kerülnek bemutatásra az azonosságokat és különbözőségeket kiemelve. A feltárt fogyasztó szokások eltérősége a kínálat kialakításának gyakorlatában a továbbiakban hasznosítható.

Kulcsszavak: ifjúsági turizmus, motiváció, utazási döntés

\section{BEVEZETÉS}

A kereslet vizsgálható egyrészt a turistatipológiák alapján, az attitûdök, elsődleges és másodlagos motivációk utazási döntésre való hatása alapján, szekunder információk és primer adatok feldolgozásával. Másrészt a turisták élményképzete, élményelvárásaik és beválásuk, vagyis az elégedettségi vizsgálatok alkothatják a kutatás tárgyát. Mindezek folytathatók külföldi-belföldi desztináció felosztásban, turisztikai termékfajtánkénti felosztásban, illetve összehasonlító kutatásként benchmark vizsgálatokkal. A kutatás minőségi ismérvekre épül, több, de korlátozott, célzottan szűrt, néhány száz elemes mintán keresztül jut az összefüggésekhez, eredmények megállapításához. A kutatás első utazása és a felmérések megtörténtek Bordeaux-ban, a kutatási tanulmány a helyi élmény tekintetében elektronikusan és nyomtatva is megjelent, tartalmazza a magyar desztinációkkal történt összehasonlítást. A kutatás további adatgyújtést célzott Durhamben (UK), amely megvalósulása után a két desztináció egyetemista fiataljainak turisztikai motivációkra vonatkozó motivációinak összehasonlító elemzésére nyílt lehetőség. A kutatás célja az utazási döntések élményelvárásainak, mint a turisztikai piacon a fogyasztói elégedettség meghatározó tényezőjének feltárása, összefüggések keresése a motivációt adó élményképzet és a beválás között. A következtetések a magyar fiatalok hasonló megkérdezésének eredményeivel összehasonlítva nemcsak fogadó, hanem küldőterületi szempontok is figyelembe vételre kerülhettek.

\section{A KUTATÁS ELMÉLETI HÁTTERE}

Az ifjúsági turizmusról készített legszélesebb körű összeállítás a Magyar Turizmus Zrt. által a 
Turizmus Bulletin XII. évfolyamában közzétett cikksorozat, amely egyrészt a hazai és nemzetközi keresletet, másrészt a hazai kínálatot elemezte. A téma szempontjából az első rész adekvát. Feldolgozásra és felhasználásra került a 2010. évi hazai Ifjúsági stratégia, amely megfelelő támpontot nyújtott az összehasonlításhoz és a következtetések levonásához. A szekunder információk összegyűjtése a külföldi turisztikai desztináció keresleti oldaláról, fogyasztói szokásokról, fogyasztói magatartásról a kérdőív összeállításánál került hasznosításra. A kutatás elméleti hátterének gerincét a fent jelzett 20062007. évi kutatások adják, melyekben komplexen szekunder adatokból levont következtetések is találhatók. A dilemma a vizsgált korcsoportról azóta is fennáll, egyes országok ifjúsági turizmuson a 15-24, míg mások a 19-29. éves korosztályt értik. Különbség a diszkrecionális jövedelemben, az utazási döntés önállóságában alapvetően beazonosítható.

A World Youth Student \& Educational Travel Confederation (WYSE) az ifjúsági turizmusnak a következő definícióját adja meg: „Az ifjúsági turizmus magában foglalja a 16-29 éves korosztály egy évnél rövidebb ideig tartó, önálló utazásait, amit részben vagy teljes egészben más kultúrák megismerésének vágya, élettapasztalat szerzése, és/vagy az utazó szokásos környezetén kívül elérhető formális vagy informális tanulási lehetőségekből származó haszonszerzés motivál."

A hivatkozott kutatás igen kiterjedt volt mind a szekunder források, mind a primer kvantitatív és kvalitatív felmérések tekintetében. Az ifjúsági turizmus jelenlegi helyzetéről az elismertsége tekintetében alacsony szintet határoz meg, a globális turizmus 20\%-át tartja köthetőnek az ifjúsági turizmushoz. Az egyik speciális jellemzője az ifjúsági turizmusban résztvevőknek, hogy a jövedelmükhöz viszonyítva a legtöbbet költő turistacsoport, s ez a költés évről-évre növekszik. Jelen vizsgálatban elemzésre kerülő Nagy-Britannia és Franciaország is küldő- és fogadóországnak is számít az ifjúsági turizmus szempontjából. Nagy-Britannia küldő-fogadó részesedése 14\%, illetve $8 \%$, Franciaországé 10\%, illetve $11 \%$. Érdemes az európai kiutazó forgalmat önállóan is megvizsgálni, ennek 12,2\%-a ifjúsági turizmus, míg a világturizmusnak csak $6 \%$-át teszi ki mindösszesen.

A kutatás kitért az utazási célokra és jellemzőkre is. Az európai fiatalok főként (93\%) szabadidős céllal utaznak ki, az össze utazás 13\%-át az 1-3 éjszakás üdülések teszik ki, a 4-5 éjszakások aránya 58\%. A szabadidős célban szerepel a klasszikus vakációzás 54\%-ban, a rokonok, barátok látogatása $17 \%$. Magas volt még a nyelvtanulási célból kiutazás, $8 \%$. A motivációk alapján képzett rangsorban a tengerparti üdülés foglal el vezető helyet, majd a városlátogatások, a körutazások, a sielés, a vidéki és helyvidéki üdülések következnek. Az idősebb korosztály motivációi között megjelent a munkakeresési célú utazás, illetve a már dolgozók incentív utazásokon, vásár és kiálításlátogatáson, konferenciákon, kongresszusokon vehetnek részt. Ez több, mint 10\%-ot tesz ki, míg a hagyományos üzleti utak, ügyféllátogatások, üzleti találkozók 3,6\%-nyi részarányt képviselnek.

A szálláshely igénybevétel szintén sajátosan alakul, $71 \%$ szállt meg kereskedelmi szálláshelyen, gyakori a szívességi szállásadás, a vadkempingezés, autóban alvás is. A kimondottan erre a szegmensre létrehívott Youth Hostelekben csupán az éjszakázók 6\%-a aludt.

A leggyakoribb a négy-hét napos tartózkodás volt (38\%). Az egy kiutazásra jutó átlagos tartózkodási idő 10,2 nap volt, egy éjszakára számítva 71 eurót költöttek. Az ifjúsági turizmus ezek alapján nem a rövid városlátogatási motivációkkal bír többségében, hanem a hosszabb, üdülési célú utazások fordulnak elő jellemzőbben.

Az UNWTO Európára vonatkozóan az ifjúsági turizmus jelentőségét a teljes európai kiutazó piac 14\%-ában határozta meg. 


\section{MAGYARORSZÁGI HELYZETKÉP - A FIATALOK BELFÖLDI UTAZÁSAI ÉS A FIATALOKNAK KÍNÁLT ATTRAKCIÓK}

A Magyar Turizmus Zrt. kutatási tanulmánya alapján a hazai ifjúsági turizmusban résztvevők legfőbb motivációja a rokonok, barátok, ismerősök meglátogatása, ennek harmada a szórakozás, sportolás, pihenés. A városnézési motiváció minimális és a kulturális rendezvények, konferenciás sem vonzóak a korosztály számára. Legkevesebbet a 15-18 évesek utaznak, az ennél fiatalabb gyerekeket a szülők jobban bekapcsolják a turizmusba. A hazai régiópreferenciáik kissé eltérnek az általános turistapreferenciáktól, az északmagyarországi és észak-alföldi régiót szívesebben látogatják a központi és a balatoni régión kívül. A választott közlekedési eszközök között hangsúlyosan jelenik meg a motor a személygépkocsi és a vasút mellett. $A$ buszos közlekedés minimális. Közel azonos arányban választják a szálláshelyi étkezést, az éttermi fogyasztást és az élelmiszerüzletekben történő élelmiszer-vásárlást.

A családi utazások önmagukban is bírnak eltéró jellemzővel, megjelennek a vízparti üdülési motivációk. Az ifjúsági turizmushoz kapcsolódó sajátosság, hogy a gyermekkori utazási élmények a későbbi önálló utazásokat is meghatározzák. Az önálló utazásoknak az iskolai végzettségnek jelentős szerepe van, a végzettség emelkedésével mind a kirándulók, mind az utazók aránya nő.

Az ifjúsági turizmus jellemző vonzerői a rendezvények, fesztiválok, találkozók, erdei iskolák és nyári táborok, azonban az utazási motivációkban mégsem jelentek meg a rangsor elején. Az ökoturisztikai vonzerőket is az ifjúság turizmusban résztvevőknek kínálják, a nemzeti parkokat az ifjúsági turizmus kiemelt célterületének tekintik, mégsem jelenik meg ez sem a rangsor elején. A szórakozás fogalom keresleti és kínálati oldali különböző értelmezése okozza a problémát, amely tisztázásával az ifjúsági turisták is elégedettebbé tehetők.

\section{A MAGYARORSZÁGRA BEUTAZÓ FIATAL TURISTÁK MOTIVÁCIÓI}

A Magyar Turizmus Zrt. 2007. évi primer kutatása alapján a belföldi szokásokkal ellentétben a motivációk között a városlátogatás a leggyakrabban említett, majd a vásárlás és a kulturális látnivalók megtekintése következik. Érdekes, hogy ezek a motivációk belföldön nem sarkallják utazásra a fiatalokat. Külföldről ugyanazokat a a városokat eljönnek megnézni a fiatalok, amelyek a belföldi fiatal turistákat nem érdeklik. A szórakozás, bulizás, majd a kikapcsolódás, passzív pihenés következik. Átlag alatti az említésszáma a helyi gasztronómia vonzerejének, a rokonok, ismerősök felkeresésének, a kulturális rendezvényeken való részvételnek (ide tartoztak a könnyúzenei koncertek, a fesztiválok, komolyzenei hangversenyek), valamint a gyógyfürdőzésnek.

\section{ANYAG ÉS MÓDSZER}

A kutatási cél megvalósítása érdekében egy hipotézis vizsgálata került kitǔzésre. Azt feltételeztem, hogy jelentősen különböznek a belföldi ifjúsági turizmusban résztvevő külföldi és a magyar hallgatók utazási motivációi. Három megkérdezetti csoporttal (magyar, francia, angol felsőoktatási hallgatók) töltettem ki a sztenderdizált kérdőívet, a külföldi fiatalok a Campus Hungary által támogatott kutatóút keretében végzett megkérdezés során válaszolták meg a kérdéseket. A három ország három városának (Bordeaux - Franciaország, Durham - Nagy-Britannia, Szolnok Magyarország) felsőoktatásban tanuló diákjai körében végzett felmérés elemzésének eredményei kerültek vizsgálatra. A városok tekintetében érdemes megemlíteni, mert az utazási motivációkat is befolyásolhatja, hogy Durham egy középkori kisváros, az egyetemisták a történelmi környezettel együtt élnek. Bordeaux egyetemistái egy mozgalmas nagyvárosban tanulnak, míg Szolnok egyetlen felsőoktatási intézménnyel nem tartozik az egyetemvárosok közé. A megkérdezések 2013. 
októberében és 2014. októberében zajlottak. 52 francia, 58 magyar és 47 angol értékelhetó kérdőív került feldolgozásra. Az összehasonlító elemzésekkel alkalom nyílt az azonosságok és különbségek feltárására.

\section{A KUTATÁS EREDMÉNYEI}

A megkérdezettek a felsőoktatási merítés miatt közel azonos átlagéletkorúak, a nemek szerinti arány a megkérdezés módszertanának eltérősége miatt, a nők nagyobb válaszadási hajlandósága okán eltér, a női nem az összehasonlíthatóság szempontjából túlreprezentált az angol válaszadók körében.

A motivációk rangsorolása tíz motiváció sorba rendezését jelentette aszerint, hogy melyiket tartotta a megkérdezett leginkább utazásra ösztönzőnek. A helyezések átlaga került összehasonlításra a három nemzet között. A szekunder információk alapján az aktivitással kapcsolatos motivációk prioritása és a társas motivációk kiemelt szerepe volt valószínúsíthető. A képzett rangsorok mutatják az azonosságokat a rangsorolás, a helyezés tekintetében (1. táblázat), az eltérések pedig a csillagdiagramon követhetőek. (1. ábra)

\begin{tabular}{|l|r|r|r|}
\hline \multicolumn{1}{|c|}{ motivációk } & \multicolumn{1}{c|}{ magyar } & \multicolumn{1}{c|}{ francia } & \multicolumn{1}{c|}{ angol } \\
\hline társaságban lenni & $8,5(1)$ & $8,9(1)$ & $8,2(1)$ \\
\hline szórakozás & $7,8(2)$ & $8,6(2)$ & $7,4(2)$ \\
\hline természeti szépségek & $7,1(3)$ & $6,5(3)$ & $6,3(3)$ \\
\hline kulturális értékek megismerése & $5,6(4)$ & $4,5(8)$ & $5,7(4)$ \\
\hline hobbi & $5,2(5)$ & $5,5(6)$ & $4,8(5)$ \\
\hline saját képességek kipróbálása & $4,5(6)$ & $5,7(5)$ & $4,4(6)$ \\
\hline különleges, extrém élmények & $4,4(7)$ & $4,6(7)$ & $4,1(8)$ \\
\hline sportolás, fizikai kihívások & $4,3(8)$ & $5,9(4)$ & $4,3(7)$ \\
\hline szokások, hagyományok megismerése & $4,2(9)$ & $3,8(9)$ & $4,0(9)$ \\
\hline nyugodt pihenés & $2,4(10)$ & $2,2(10)$ & $2,5(10)$ \\
\hline
\end{tabular}

1. táblázat $A$ három nemzet ifjúsági turizmusában résztvevők motivációs rangsora

Forrás: saját felmérés 2013-14.

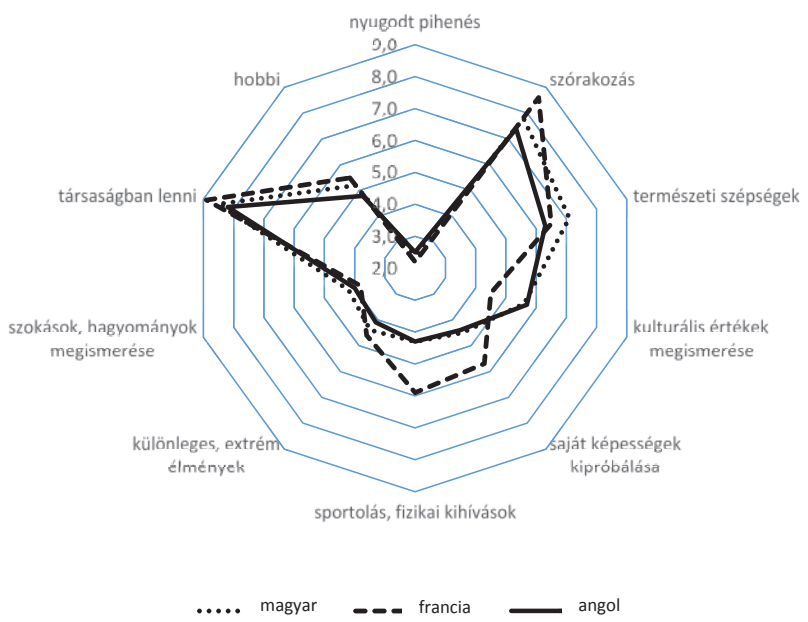

1. ábra Az ifjúsági turizmus motivációinak eltérései 
Kóródi Márta: Az ifjúsági turizmus motivációi francia és angol egyetemisták megkérdezése alapján

A rangsorok tipikus, fiatalos motivációkat mutatnak, a sorrend a három nemzet közül a magyar és angol válaszadók szerint csak két esetben tér el, a sport aktivitás és kihívás jelleg cserélődött fel, míg a francia fiatalok az aktivitást jobban szeretik és a kultúrát kevésbé motiválónak tekintik.

A legjelentősebb eltérések a sportolás, a szórakozás és a természeti és a kulturális értékek motiváló hatása között volt. A magyarok ez utóbbiak iránt vonzódnak jobban, míg az angolok kulturális érdeklődése kiemelkedő. Közös a szórakozási célú utazás és még nem nyitott egyik fiatal csoport sem a hagyományok, szokások megismerésére.
A másik fő kérdéscsoport arra vonatkozott, hogy mely tényezők játszanak szerepet az utazási döntés során. A négyfokozatú skálán adott válaszokat rendre 1-4 pontszámokkal értékelve 12 tényező rangsorát lehetett kialakítani. A három nemzet válaszait a 2 . ábra szemlélteti. A jövedelem-költség viszonylatban a magyarok a legérzékenyebbek, ugyanakkor a lehető legtöbb látnivalót szeretnék megismerni. A francia fiatalok kényelemszeretők, ugyanakkor dinamikusak mind a programok, mind a közlekedés tekintetében. Az angolok hagyománytisztelők, adnak a korábbi tapasztalatokra és kevésbé vállalkozók, kalandkeresők. nem tartják meghatározónak az évszakot és a megközelíthetőséget, ezek leküzdhető problémát jelentenek számukra.

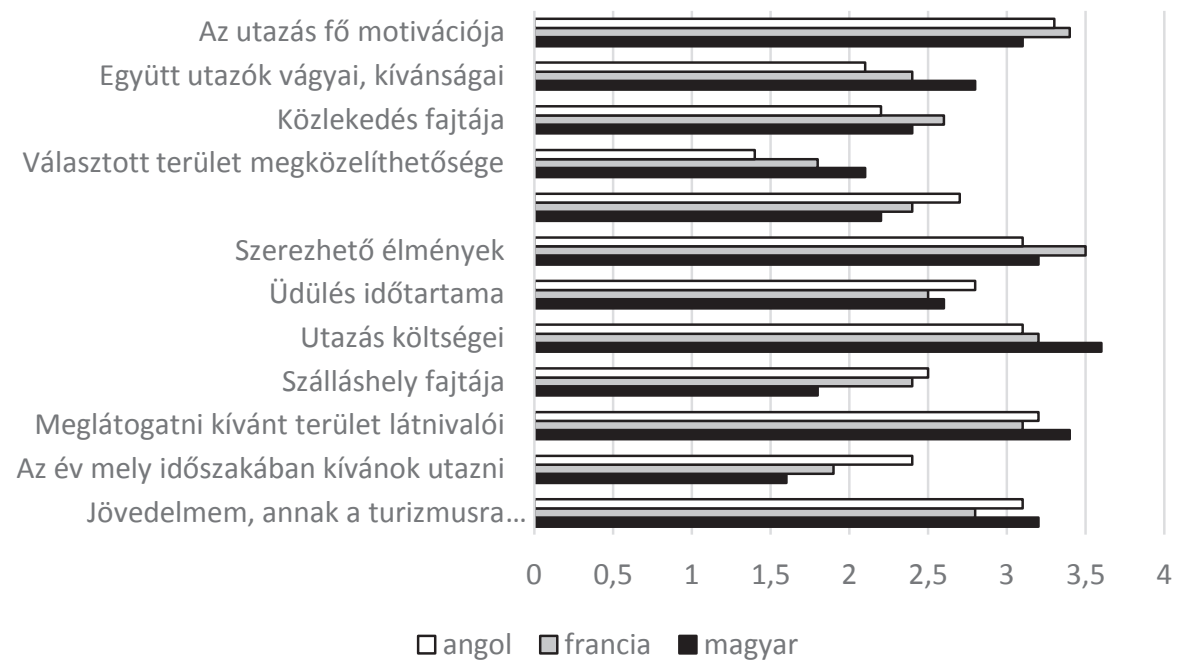

2. ábra Az ifjúsági turizmus motivációi az utazási döntésekben

Forrás: saját felmérés

Fontos tényezőként emelhető ki a kutatások alapján a megszerezhető élmény. Ez felveti az ifjúsági turizmusban is az élménymenedzsment jelentőségét, az élményígéretek és a megvalósulás összhangjának megteremtését.

\section{Összegzés}

Az ifjúsági turizmus jellemzőinek változása párhuzamba vonható a turizmus tendenciáinak megfelelő UNWTO előrejelzéssel, valamint a WYSE ifjúsági turizmusra vonatkozó becslésével. $A$ várható növekedés egyértelmú, a kontinensek közötti utazások aránya nőni fog. A demográfiai folyamatok, a korosztály létszámának csökkenése az abszolút adatok becslését jelentősen befolyásolhatja. Ugyanakkor az életszínvonal növekedése pozitív tényező, valószínűsíthetően kompenzálja az 
előző tényező negatív hatását. A primer kutatások alapján igazolódott, hogy a fiatalok az átlagos turistákhoz képest eltérő utazási szokásokkal rendelkeznek, amelyek eltérő motivációkon alapulnak, érdemes a turisztikai vállalkozások számára a célcsoportjukat kor szerint szegmentálni. Az értékesítési és kommunikációs csatornák megválasztásában is figyelembe kell venni a fiatalok elérésének sajátosságait.

\section{FELHASZNÁLT IRODALOM}

[1] Mester Tünde (2008) Ifjúsági turizmus Magyarországon - I. rész. Turizmus Bulletin XII. évfolyam 2. szám pp.2-13.

[2] Mester Tünde (2009) Ifjúsági turizmus Magyarországon - II. rész. Turizmus Bulletin XIII. évfolyam 1. szám pp.3-13

[3] Kóródi M. (2012). A másodlagos utazási motivációk megjelenése a vízparti turizmusban In: Economica V. új évfolyam. II. különszám pp.94-103. 